\title{
Assessing factors affecting professional bus drivers in Central Java, Indonesia
}

\author{
Bayu Yoni Setyo Nugroho ${ }^{1}$, Vilda Ana Veria Setyawati ${ }^{1}$ and Slamet Isworo ${ }^{2, *}$ \\ ${ }^{1}$ Public Health Department, Faculty of Health Sciences, University of Dian Nuswantoro, Semarang, Indonesia. \\ ${ }^{2}$ Environmental Health Department, Faculty of Health Sciences, University of Dian Nuswantoro, Semarang, Indonesia.
}

GSC Biological and Pharmaceutical Sciences, 2021, 14(03), 019-026

Publication history: Received on 23 January 2021; revised on 26 February 2021; accepted on 01 March 2021

Article DOI: https://doi.org/10.30574/gscbps.2021.14.3.0059

\begin{abstract}
Public transportation is a key solution to a connecting city in Indonesia country. An important factor of driver behavior and driver fatigue is the potential for loss in this field. This study aims to identify traffic loss risk factors associated with demographic characteristics, fatigue levels, body mass index, driver experience blood pressure levels, and inappropriate driver attitudes on public transport as well as to find out the effects of fatigue levels. This research is a cross-sectional technique with descriptive analytics. The sample in this study was 67 professional bus drivers with licenses in Central Java Province, Indonesia. Data collection in the month 1-30 January 2021. Based on the results of the study showed that 67 respondents, $77.6 \%$ experienced severe level fatigue, $85.1 \%$ worked more than 8 hours, $73.1 \%$ had a smoking habit. For Body Mass Index 29.9\% are overweight, 65.7\% have prehypertensive blood pressure levels.
\end{abstract}

The fatigue experienced by public transport drivers is categorical as heavy (77.6\%). periodic checks are required regarding the level of fatigue so that the risk of traffic accidents does not occur. The policy regarding working hours must be carried out from an average of 13.82 hours per day to 8 hours, according to regulations and a bus driver's working period of more than 5 years is a record of future health problems.

Professional bus drivers have a dangerous level of fatigue, so there needs to be a change in the work system in order to avoid the risk of traffic accidents related to public transportation.

Keywords: Professional bus drivers; Fatigue; Transportation; Risk Factors; Health Problems

\section{Introduction}

Safety and health are an important part of any modern social life. This activity not only covers the material environment and work environment but is related to the human relationship of a machine and work systems. It is therefore important to understand the role of safety and health in all human activities. it is important for every human being to prepare for the various risks they will face in each life [1]. Technological changes in transportation are becoming new challenges in the field of safety and health. Technology that has been installed in vehicles from automotive manufacturers as well as additional technologies coming from outside the automotive manufacturer. The behavior of transport drivers who use mobile phones while working, turn the tv on and turn on the mp3 into a harmful component [2].

More than 1.2 million people die each year from traffic around the world, making road traffic injuries the leading cause of death globally. Most of these deaths occurred in low- and middle-income countries where rapid economic growth was accompanied by increased motorization and highway traffic accidents. In addition to road deaths, up to 50 million people suffer non-fatal injuries each year due to road traffic accidents, while there are additional indirect health consequences associated with the current growing epidemic [3].

\footnotetext{
* Corresponding author: Slamet Isworo

Environmental Health Department, Faculty of Health Sciences, University of Dian Nuswantoro, Semarang, Indonesia.
} 
Public transportation is important for the province with the ranked number three population in Indonesia, Central Java Province with a population of 37 million people [4]. Semarang is the capital city becomes the business and economic center in Central Java Province, while Surakarta city is the second most advanced city in Central Java Province. The distance between this city is \pm 112 kilometers and the travel duration of 3 hours 30 minutes. The transportation industry in world contributes high cases of accidents and injuries where the causes include, lack of management explanations at the beginning of work, unbalanced distance and time demands, and general transportation driver income factors [5]. Figure 1 shows the bus route from the city of Surakarta to the city of Semarang (google map), as follows: [6]

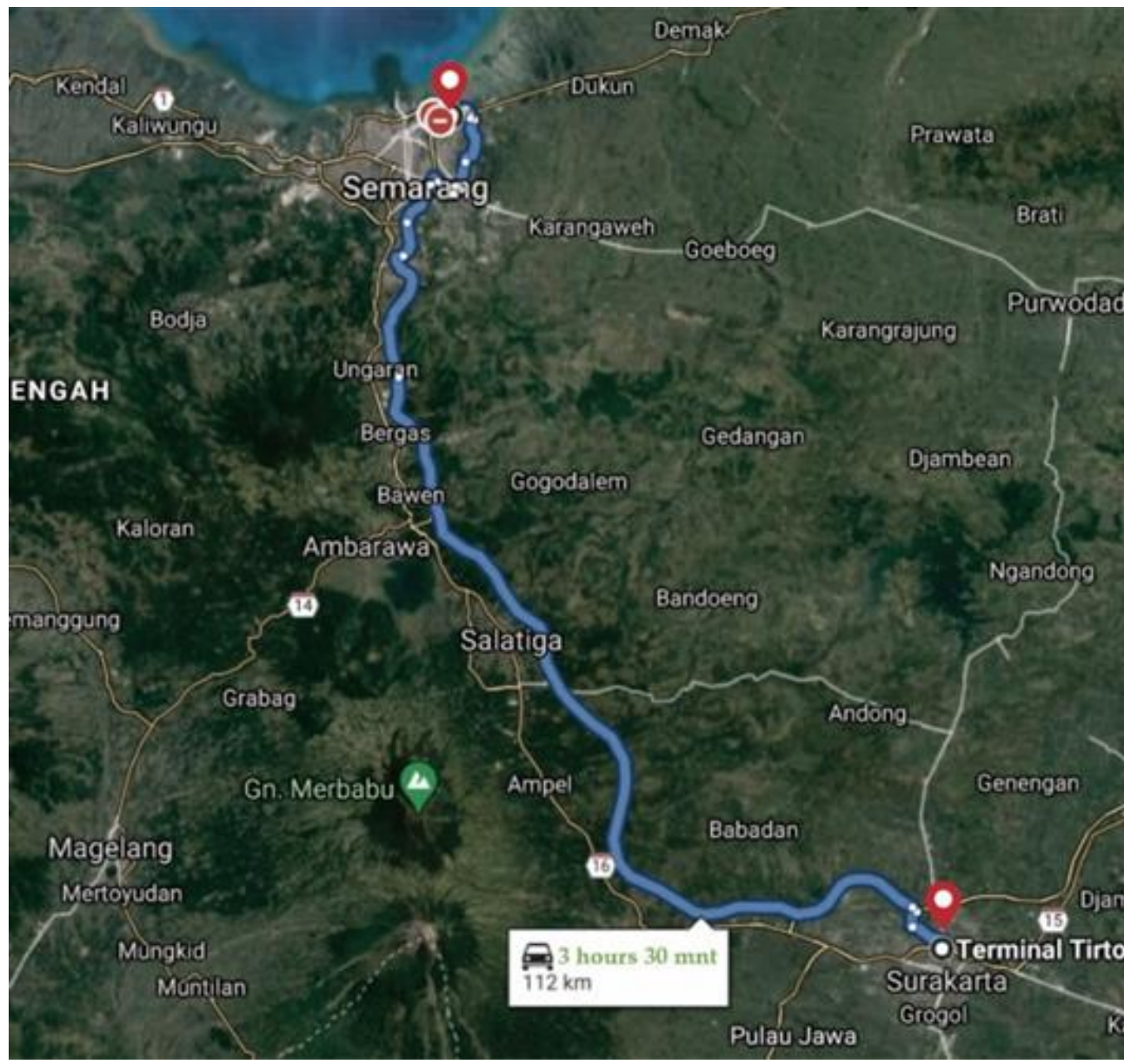

Figure 1 Surakarta bus route to Semarang city

The use of bus model transportation is generally based on traffic density that makes people saturated using private vehicles and good public transportation trust. Attention to public transport drivers in Indonesia still has many weaknesses, generally, attention is given when major events such as Muslim festivals, Christmas, New Year. Many people come back to the village to meet their families [7].

The transportation industry contributes high cases of accidents and injuries were the causes include lack of management explanations at the beginning of work, unbalanced distance and time demands, and general transportation driver income factors [5].

The human factor appears as the most important factor since it affects active and passive safety in various ways. Driving in a state of exhaustion is one of the most important elements besides gender, age, ability, training skills, attitude, experience, behavior. Fatigue is a human factor that greatly influences mood and motivation, as well as drowsiness and human cognitive function and ability, and therefore becomes the driver [8].

Safety is a common definition in everyday life, research related to the public transport sector is still limited, especially in developing countries. The world estimates there are about one million deaths from road accidents and ten million injuries each year, many with long-term disabilities. Nearly $70 \%$ of these occur in developing or developing countries 
[9]. Accidents contributed to 1.35 million deaths worldwide according to who in 2018. Indonesia ranks fifth in the world with a contributor to traffic deaths. More than $0.5 \%$ of accidents are contributed by public transport [10].

The government's challenge in realizing the culture of people using public transportation massively still has problems. The accident data still shows a high trend in Indonesia in 2010 as much as 95,906 and experienced growth of $16.59 \%$ annually. Public transportation types such as buses accounted for 4,808 accidents [11]. Traffic accident data in Central Java Province in 2018 reached 4,876 incidents with 1,062 fatalities and 5.73 minor injuries. Therefore it is important to know the factors related to fatigue and behavior of bus drivers to improve safety and health in the workplace. This paper provides a review of the research methods used to assess bus driver behavior and describe fatigue, in this study also provides an overview of the health of bus drivers. This will explore the relationship between bus driver fatigue and possible factors.

\section{Methods}

The research using observational design with cross-sectional approach was conducted at Terboyo station in Semarang city within one month, data collection on 1-30 January 2021 using an accidental sampling technique. The respondents of the study were all drivers of the Surakarta-Semarang route bus in Central Java Province, Indonesia. Drivers who are willing to be respondents as many as 67 people. The data were collected using demographic questionnaires, as well as measuring fatigue levels, blood pressure, and body mass index. All respondents involved in the study had signed an informed consent sheet.

Descriptive presentation of data uses frequency distribution and cross table to look at bivariate analysis of narrative dissertations. Instruments used to obtain public transport driver attitudes using the Driver Behaviour Questionnaire (DBQ) have been widely used in other countries' studies [12] [13], blood pressure reducer using Sphygmomanometer [10] while individual fatigue measurements using reaction time [14] and body mass index using weight scales and microtoise [15] Bivariate analysis using Chi-Square and Fisher Exact tests with a 5\% degree of meaning. Ethics approval from the Health Research Ethics Committee (KEPK) of Muhammadiyah University Semarang Number 451/KEPKFKM/UNIMUS/ 2020.

\section{Results}

In our setting, there were 67 bus drivers, who fully completed the questionnaires and all agreed to provide their informed consent. Of the 67 respondents, Characteristics of respondents can be seen in Table 1 . Most of the 30 -yearolds were $79.1 \%$ of the 23 -year-olds and 69 were the oldest and the average age was 42.9 years with a standard deviation of 10,874 . The highest length $>5$-year period was $85.1 \%$ where the range worked between 2 to 40 years, the average length of work was 17.36 years with a standard deviation of 10.11 years. Working duration of $95.5 \%$ more than 8 hours per day with the lowest duration of 8 hours per day and the longest 24 hours/day, the average duration of work 13.82 hours per day with a standard deviation of 3.47 hours per day. Other frequency data showed the results of smoking habits as much as $73.1 \%$ were 40 respondents consumed cigarettes between 1-20 cigarettes per day with an average of 11 cigarettes consumed per day.

Table 1 results show the percentage of body mass index most categories Overweight as much as 20 (29.9\%) while the results related to obesity level 2 as much as $8(11.9 \%)$. Data related to not having a history of the disease as much as 59 (88.1\%), 7 respondents have a history of non-communicable diseases. Blood pressure data obtained 44 (65.7\%) prehypertension where the category is in the systole range of $120-139 \mathrm{mmHg}$ and diastole $80-89 \mathrm{mmHg}$. 
Table 1 Characteristics of respondents.

\begin{tabular}{|c|c|c|}
\hline Characteristics & n: 67 & $\%$ \\
\hline \multicolumn{3}{|l|}{ Age (years) } \\
\hline$\leq 30$ & 53 & 79.1 \\
\hline$>30$ & 14 & 20.9 \\
\hline \multicolumn{3}{|l|}{ Years of work (years) } \\
\hline$\leq 5$ & 10 & 14.9 \\
\hline$>5$ & 57 & 85.1 \\
\hline \multicolumn{3}{|l|}{ Duration of work (hours / day) } \\
\hline$\leq 8$ & 3 & 4.5 \\
\hline$>8$ & 64 & 95.5 \\
\hline \multicolumn{3}{|l|}{ Smoking habits } \\
\hline No smoking & 18 & 26.9 \\
\hline Smoking & 49 & 73.1 \\
\hline \multicolumn{3}{|l|}{ Number of cigarettes } \\
\hline$\leq 20$ cigarettes / day & 40 & 81.6 \\
\hline$>20$ cigarettes / day & 9 & 18.4 \\
\hline \multicolumn{3}{|l|}{ Body Mass Index (BMI) } \\
\hline Underweight $(<18.5)$ & 3 & 4.5 \\
\hline Normal (18.6-22.9) & 19 & 28.4 \\
\hline Overweight (23-24.9) & 20 & 29.9 \\
\hline Obesity Level 1 (25-29.9) & 17 & 25.4 \\
\hline Obesity Level 2 (> 30) & 8 & 11.9 \\
\hline \multicolumn{3}{|l|}{ History of disease } \\
\hline Yes & 8 & 88.1 \\
\hline No & 59 & 11.9 \\
\hline \multicolumn{3}{|l|}{ Blood pressure } \\
\hline Normal(<120 mmHg / <80 mmHg) & 14 & 20.9 \\
\hline Prehypertension (120-139 mmHg /80-90 mmHg) & 44 & 65.7 \\
\hline Hypertension (14-159 mmHg / 90-99 mmHg) & 9 & 13.4 \\
\hline \multicolumn{3}{|l|}{ Reaction Timer (millisecond) } \\
\hline Normal $(150-240)$ & 0 & 0 \\
\hline Mild Work Fatigue $(>240-<410)$ & 2 & 3 \\
\hline Moderate Fatigue $(>410-<580)$ & 13 & 19.4 \\
\hline Heavy Work Fatigue (> 580) & 52 & 77.6 \\
\hline
\end{tabular}

Source: Primary Data. 2021

Based on the mean on the DBQ questionnaire obtained three question items that most bus drivers do. i.e. I honk the bus horn when I feel distracted with the driver / other riders (Mean 3.15). I drive very close to the car that is in front as a signal of the driver's pain to go faster or move away (Mean 3.03). I always stop away from the traffic lights (Mean 2.7). While the three items of questions that the bus driver did the least I misread the traffic signs resulted in me entering the wrong lane (Mean 1.09). I have a bad memory of the road I was going through (Mean 1.13). I did not notice pedestrians crossing when changing from the main road to the other side (Mean 1.13). 
Table 2 Driver Behaviour Questionnaire (DBQ)

\begin{tabular}{|c|c|c|c|c|}
\hline$Q$ item & Item & Mean & Std. Deviasi & Variance \\
\hline 9 & $\begin{array}{l}\text { I turn on the bus horn when I feel distracted by the other } \\
\text { driver/ rider }\end{array}$ & 3.15 & 1.004 & 1.008 \\
\hline 1 & $\begin{array}{l}\text { I drive close to the vehicle that is in front as a signal to the } \\
\text { driver to go faster or get out of the way }\end{array}$ & 3.03 & 0.758 & 0.575 \\
\hline 22 & I always stop away from traffic lights & 2.7 & 0.798 & 0.637 \\
\hline 5 & $\begin{array}{l}\text { I don't like certain types of driving techniques (inconside } \\
\text { what they say) and I show such dislike }\end{array}$ & 2.57 & 1.104 & 1.219 \\
\hline 2 & $\begin{array}{l}\text { I was speeding at a crossroads when the lights went from } \\
\text { yellow to red }\end{array}$ & 2.39 & 0.627 & 0.393 \\
\hline 10 & $\begin{array}{l}\text { I remained on the usual route until it was closed for some } \\
\text { reason before I decided to move to another road/ toll road }\end{array}$ & 2.28 & 0.831 & 0.691 \\
\hline 6 & $\begin{array}{l}\text { I can't wait when there's a slow rider on the right track and } \\
\text { overtaking in the left lane }\end{array}$ & 2.22 & 0.85 & 0.722 \\
\hline 11 & $\begin{array}{l}\text { I sometimes accidentally overtake a rider who is turning on } \\
\text { the left/right sign light }\end{array}$ & 2.18 & 0.673 & 0.452 \\
\hline 23 & $\begin{array}{l}\text { I turn on the light or other part when I intend to turn on the } \\
\text { wipers }\end{array}$ & 2.00 & 0.771 & 0.594 \\
\hline 24 & $\begin{array}{l}\text { I intend to go through line A but instead I go through line B } \\
\text { because it is common in this line }\end{array}$ & 2.04 & 0.787 & 0.619 \\
\hline 7 & I sometimes race with other drivers/other bus routes & 2.03 & 0.717 & 0.514 \\
\hline 4 & I don't really care about the speed limit board & 1.73 & 0.709 & 0.502 \\
\hline 3 & $\begin{array}{l}\text { I don't care about speed limits in public facilities like } \\
\text { hospitals }\end{array}$ & 1.72 & 0.454 & 0.206 \\
\hline 14 & $\begin{array}{l}\text { When queuing and turning right/left to enter the main } \\
\text { road. I focused on paying attention to the flow of main road } \\
\text { traffic so that I almost hit the road user in front of me }\end{array}$ & 1.70 & 0.759 & 0.576 \\
\hline 17 & $\begin{array}{l}\text { I brake suddenly on slippery roads or turn in the wrong } \\
\text { direction when the wheels are slippery }\end{array}$ & 1.69 & 0.528 & 0.279 \\
\hline 12 & $\begin{array}{l}\text { It's been a long time since i've given other drivers a chance } \\
\text { on a narrow road to avoid a collision }\end{array}$ & 1.64 & 0.753 & 0.560 \\
\hline 21 & $\begin{array}{l}\text { I crashing something while turning the vehicle around and } \\
\text { was sure I hadn't seen anything in the way before }\end{array}$ & 1.57 & 0.583 & 0.34 \\
\hline 15 & $\begin{array}{l}\text { I don't attention the rearview mirror when opening doors } \\
\text { or changing lanes }\end{array}$ & 1.55 & 0.558 & 0.312 \\
\hline 16 & $\begin{array}{l}\text { I don't pay attention to the speed of the vehicle that enters } \\
\text { when overtaking }\end{array}$ & 1.54 & 0.532 & 0.283 \\
\hline 8 & When I'm angry with another driver then i'll catch up & 1.37 & 0.693 & 0.48 \\
\hline 18 & $\begin{array}{l}\text { I got into the wrong lane when approaching a roundabout } \\
\text { or a deviation }\end{array}$ & 1.28 & 0.454 & 0.206 \\
\hline 20 & I sometimes forget to leave my bus when at the bus station & 1.22 & 0.42 & 0.176 \\
\hline 13 & $\begin{array}{l}\text { I didn't notice pedestrians crossing when changing from } \\
\text { the main road to the other side }\end{array}$ & 1.13 & 0.457 & 0.209 \\
\hline 25 & I have a bad memory of the path I'm going through & 1.13 & 0.694 & 0.482 \\
\hline 19 & $\begin{array}{l}\text { I wrong read the traffic sign causing me to get in the wrong } \\
\text { lane }\end{array}$ & 1.09 & 0.288 & 0.083 \\
\hline
\end{tabular}


Table 3 The results of the bivariate analysis of characteristic variables with driver fatigue.

\begin{tabular}{|c|c|c|c|c|c|c|c|}
\hline \multirow{3}{*}{ Characteristics } & \multicolumn{4}{|c|}{ Fatigue (n: 65) } & \multirow{2}{*}{\multicolumn{2}{|c|}{$p$}} & \multirow[t]{3}{*}{ OR (CI) } \\
\hline & \multicolumn{2}{|c|}{ Moderate } & \multicolumn{2}{|c|}{ Weight } & & & \\
\hline & $\mathbf{n}$ & (\%) & $\mathbf{n}$ & (\%) & Chi & Fis & \\
\hline $\begin{array}{l}\text { Age (years) } \\
\leq 30 \\
>30\end{array}$ & $\begin{array}{l}6 \\
7\end{array}$ & $\begin{array}{l}46.2 \\
13.5\end{array}$ & $\begin{array}{l}7 \\
45\end{array}$ & $\begin{array}{l}53.8 \\
86.5 \%\end{array}$ & $0.008^{*}$ & $0.016^{*}$ & $\begin{array}{l}5.510 \\
(1.428-21.260)\end{array}$ \\
\hline $\begin{array}{l}\text { Years of work (years) } \\
\leq 5 \\
>5\end{array}$ & $\begin{array}{l}4 \\
9\end{array}$ & $\begin{array}{l}44.4 \\
16.1\end{array}$ & $\begin{array}{l}5 \\
47 \\
\end{array}$ & $\begin{array}{l}55.6 \\
83.9\end{array}$ & $0.048^{*}$ & $0.070^{*}$ & $\begin{array}{l}4.178 \\
(0.936-18.644)\end{array}$ \\
\hline $\begin{array}{l}\text { Duration of work (hours / } \\
\text { day) } \\
\text { Mean } \leq 13.82 \\
\text { Mean }>13.82\end{array}$ & $\begin{array}{l}5 \\
8\end{array}$ & $\begin{array}{l}15.2 \\
25.0\end{array}$ & $\begin{array}{l}28 \\
24\end{array}$ & $\begin{array}{l}84.8 \\
75.0\end{array}$ & 0.321 & 0.367 & $\begin{array}{l}0.536 \\
(0.155-1.857)\end{array}$ \\
\hline $\begin{array}{l}\text { Smoking habit } \\
\text { No smoking } \\
\text { Smoking } \\
\end{array}$ & $\begin{array}{l}2 \\
11\end{array}$ & $\begin{array}{l}11.1 \\
23.4 \\
\end{array}$ & $\begin{array}{l}16 \\
36 \\
\end{array}$ & $\begin{array}{l}88.9 \\
76.6 \\
\end{array}$ & 0.268 & 0.326 & $\begin{array}{l}2.444 \\
(0.485-12.323)\end{array}$ \\
\hline $\begin{array}{l}\text { Number of cigarette } \\
\leq 20 \text { cigarettes / day } \\
>20 \text { cigarettes / day }\end{array}$ & $\begin{array}{l}11 \\
2\end{array}$ & $\begin{array}{l}19.6 \\
22.2\end{array}$ & $\begin{array}{l}45 \\
7\end{array}$ & $\begin{array}{l}80.4 \\
77.8\end{array}$ & 0.857 & 1.000 & $\begin{array}{l}0.856 \\
(0.156-4.703)\end{array}$ \\
\hline $\begin{array}{l}\text { Body Mass Index (BMI) } \\
\text { Underweight }(<18.5) \\
\text { Normal }(18.6-22.9) \\
\text { Excess body weight }(23-24.9) \\
\text { Obesity Level } 1(25-29.9) \\
\text { Obesity Level } 2(>30)\end{array}$ & $\begin{array}{l}2 \\
6 \\
3 \\
1 \\
1\end{array}$ & $\begin{array}{l}66.7 \\
31.6 \\
15.0 \\
6.3 \\
14.3\end{array}$ & $\begin{array}{l}1 \\
13 \\
17 \\
15 \\
6 \\
\end{array}$ & $\begin{array}{l}33.3 \\
68.4 \\
85.0 \\
93.7 \\
85.7\end{array}$ & 0.091 & & - \\
\hline $\begin{array}{l}\text { Blood pressure } \\
\text { Normal } \\
\text { Pre-hypertension } \\
\text { Hypertension }\end{array}$ & $\begin{array}{l}0 \\
11 \\
2\end{array}$ & $\begin{array}{l}00 \\
26.2 \\
22.2\end{array}$ & $\begin{array}{l}14 \\
31 \\
7\end{array}$ & $\begin{array}{l}100 \\
73.8 \\
77.8\end{array}$ & 0.104 & & - \\
\hline
\end{tabular}

Chi: chi-square; Fis: fisher's exact

Respondent with a $>30$ years old has a statistically significant relationship with fatigue levels with chi-square test 0.008 and fisher exact $0.016(\mathrm{OR}=5.510$. CI95\%: $(1.428-21.260)$ ). Long working $>5$ years has a statistically significant trend with chi-square test 0.048 and fisher exact $0.070(\mathrm{OR}=4.178 . \mathrm{CI} 95 \%$ : $(0.936-18.644))$.

\section{Discussion}

The purpose of this study was to assess the objective fatigue of drivers of public vehicles with characteristic variables. $77.6 \%$ or 52 respondents were highly fatigued. This result is similar to that of bus drivers in Taiwan where fatigue causes psychological disorders and the final stages lead to the risk of road accidents [16]. [17]. Older $>30$ years have a higher tendency to cause fatigue. This study is comparable to previous results where ages 31-35 have a tendency to experience neglect in drivers [18].

This study also produced an overview of driver behavior by using a Driver Behaviour Questionnaire (DBQ) measuring instrument that has 3 dimensions namely the first violation carried out by the driver of a public vehicle intentionally. Secondly errors or inappropriate attitudes of drivers of public vehicles as well as mistakes made by accident and the 
third Lapse or irregularities that are not visible when performing such actions are sometimes related to the decrease or loss of cohesion of the driver of public vehicles.

The first dimension is related to violations there are 3 items of questions that are often experienced by drivers of public vehicles namely; I turn on the bus horn when I feel distracted with the driver / other riders. I drive very close to the car in front as a signal of the driver's pain to go faster or get out of the way and the third I do not like some certain driving techniques (reckless) and I show that sense. These results have differences with previous studies The deviations that are drivers are very dangerous and risk causing traffic accidents [19]. Over-30s dominate with severe fatigue status. Older age or after having a public transportation driver's license (SIM) has the opportunity to make deviations in driving in the absence of supervision [20].

The second dimension relates to errors or inappropriate behaviour or failure to act. the result of most questions the driver does sometimes accidentally overtake the rider who is turning on the left sign light/right this is very dangerous because it can cause accidents [21].

The third dimension deals with items that are with driver deviations. The results resulted in the most positive items. namely stopping away from traffic lights in line with research conducted in China that resulted in positive behaviour reducing $53 \%$ of road accidents [22].

Finally, this study has limitations that must be considered. First the study focused on Indonesia as a developing country. This research can be generalized to different regions that have similar characteristics. There are several variables that are not researched in this study that can affect the results among others business owner support family factors.

\section{Conclusion}

Fatigue experienced by heavy categorical public transport drivers (77.6\%). bus transportation service providers must conduct periodic checks related to fatigue levels thus allowing a decrease in the risk of traffic accidents. Policymaking regarding working hours must be done because the results of the study stated that an average of 13.82 hours per day. in addition to exceeding the 8-hour work rule may be harmful to driver health and passenger safety. Bus driver's working period of more than 5 years becomes a health problem in the future. This data could be an initial assessment of the health and health efforts in the workplace.

\section{Compliance with ethical standards}

\section{Acknowledgments}

The author would like to thank the public transportation managers of Central Java Province. Indonesia who have offered for this research and all respondents in this study. Source of funding: this study received no specific grants from funding agencies in the public. commercial or non-profit sectors.

\section{Disclosure of conflict of interest}

The authors declare no conflict of interest.

\section{Statement of informed consent}

Informed consent was obtained from all participants included in the study.

\section{References}

[1] S Vargova. J Namesanska. J Sinay. Integrated work safety of public transport drivers. Theor. Issues Ergon. Sci. Jan. $2017 ; 18(1): 24-34$.

[2] KJ Parnell. NA Stanton. K Plant. Where are we on driver distraction? Methods. approaches and recommendations. Theor. Issues Ergon. Sci. Sep. 2018; 19(5): 578-605.

[3] WHO | Global status report on road safety 2015. The Global status report on road safety 2015 was superseded by the Global status report on road safety 2018 which was launched on 7 December 2018. WHO. 2018. 
[4] BPS-Statistics of Jawa Tengah Province. Jawa tengah province in figures 2021. Catalog : 1102001.33; ISSN : 02152177; 2021

[5] Hughes B, Falkmer T, Anund A. Road safety policy and practice: The relevance of Australasian road safety strategies in a future context. Journal of the Australasian College of Road Safety. 2019 Feb;30(1):34.

[6] Gibson R, Erle S. Google maps hacks. " O'Reilly Media, Inc."; 2006 Jan 17.

[7] VI Yulianto. Is the Past another Country? A Case Study of RuralUrban Affinity on Mudik Lebaran in Central Java. J. Indones. Soc. Sci. Humanit. 2011; 4: 49-66.

[8] P Obst. K Armstrong. S Smith. T Banks. Age and gender comparisons of driving while sleepy: Behaviours and risk perceptions. Transp. Res. Part F Traffic Psychol. Behav. Nov. 2011; 14(6): 539-542.

[9] TB Joewono. H Kubota. Safety And Security Improvement In Public Transportation Based On Public Perception In Developing Countries. IATSS Res. Jan. 2006; 30(1): 86-100.

[10] M Ma. X Yan. H Huang. M Abdel-Aty. Safety of Public Transportation Occupational Drivers: Risk Perception. Attitudes and Driving Behavior. Transp. Res. Rec. J. Transp. Res. Board. Jan. 2010; 2145(1): 72-79.

[11] WAJ Antika Adzary Sekar Fadlilah. Irwan Iftadi. "Hierarchical Task Analysis (HTA) Pengemudi Bus Batik Solo Trans." Prosiding SNST ke-9. 2018.

[12] M Maslać. B Antić. K Lipovac. D Pešić. N Milutinović. Behaviours of drivers in Serbia: Non-professional versus professional drivers." Transp. Res. Part F Traffic Psychol. Behav. Jan. 2018; 52: 101-111.

[13] D. Mohamed. B. Lotfi. Dimensions of aberrant driving behaviours in Tunisia: identifying the relation between Driver Behaviour Questionnaire results and accident data." International Journal of Injury Control and Safety Promotion. vol. 23 no. 4. Taylor and Francis Ltd. Oct. 01. 2016; 337-345.

[14] AK Yadav. NR Velaga. Modelling the relationship between different Blood Alcohol Concentrations and reaction time of young and mature drivers. Transp. Res. Part F Traffic Psychol. Behav. Jul. 2019; 64: 227-245.

[15] Wiegand DM, Hanowski RJ, McDonald SE. Commercial drivers' health: a naturalistic study of body mass index, fatigue, and involvement in safety-critical events. Traffic injury prevention. 2009 Nov 18;10(6):573-9.

[16] HK Chen. HW Chou. JW Su. FH Wen. Structural interrelationships of safety climate stress inattention and aberrant driving behavior for bus drivers in Taiwan. Transp. Res. Part A Policy Pract. Dec. 2019; 130: 118-133.

[17] Z Deng. D Chu. C Wu. Y He. J Cui. Curve safe speed model considering driving style based on driver behaviour questionnaire." Transp. Res. Part F Traffic Psychol. Behav. Aug. 2019; 65: 536-547.

[18] G. Sikander. S. Anwar. Driver fatigue detection systems: A review.” IEEE Trans. Intell. Transp. Syst. 2018; 20(6): 2339-2352.

[19] S Koppel et al. The Driver Behaviour Questionnaire for older drivers: Do errors. violations and lapses change over time? Accid. Anal. Prev. 2018; 113: 171-178.

[20] GD Roman. D Poulter. E Barker. FP McKenna. R Rowe. Novice drivers individual trajectories of driver behavior over the first three years of driving. Accid. Anal. Prev. Jun. 2015; 82: 61-69.

[21] MJM. Sullman. AN Stephens. JE Taylor. Dimensions of aberrant driving behaviour and their relation to crash involvement for drivers in New Zealand. Transp. Res. Part F Traffic Psychol. Behav. Oct. 2019; 66: 111-121.

[22] W Han. J Zhao. Driver behaviour and traffic accident involvement among professional urban bus drivers in China. Transp. Res. Part F Traffic Psychol. Behav. Oct. 2020; 74: 184-197. 